\title{
Wind regime for long-ridge yardangs in the Qaidam Basin, Northwest China
}

\author{
GAO Xuemin ${ }^{1,2,3^{*}}$, DONG Zhibao ${ }^{4}$, DUAN Zhenghu ${ }^{1}$, LIU Min ${ }^{5}$, CUI Xujia ${ }^{5}$, LI Jiyan ${ }^{5,6}$ \\ ${ }^{1}$ Key Laboratory of Desert and Desertification, Northwest Institute of Eco-Environment and Resources, Chinese Academy of \\ Sciences, Lanzhou 730000, China; \\ ${ }^{2}$ University of Chinese Academy of Sciences, Beijing 100049, China; \\ ${ }^{3}$ School of Tourism and Public Administration, Jinzhong University, Jinzhong 030619, China; \\ ${ }^{4}$ School of Geography and Tourism, Shaanxi Normal University, Xi'an 710062, China; \\ ${ }^{5}$ School of Geography Science, Taiyuan Normal University, Jinzhong 030619, China; \\ ${ }^{6}$ Key Laboratory of Education Ministry on Environment and Resources in Tibetan Plateau, Qinghai Normal University, Xining \\ 810008 , China
}

\begin{abstract}
Yardangs are typical aeolian erosion landforms, which are attracting more and more attention of geomorphologists and geologists for their various morphology and enigmatic formation mechanisms. In order to clarify the aeolian environments that influence the development of long-ridge yardangs in the northwestern Qaidam Basin of China, the present research investigated the winds by installing wind observation tower in the field. We found that the sand-driving winds mainly blow from the north-northwest, northwest and north, and occur the most frequent in summer, because the high temperature increases atmospheric instability and leads to downward momentum transfer and active local convection during these months. The annual drift potential and the ratio of resultant drift potential indicate that the study area pertains to a high-energy wind environment and a narrow unimodal wind regime. The wind energy decreases from northwest to southeast in the Qaidam Basin, with the northerly winds in the northwestern basin changing to more westerly in the southeastern basin. The strong and unidirectional wind regime for the long-ridge yardangs in the northwestern Qaidam Basin results from the combined effects of topographic obstacles such as the Altun Mountains and of the interaction between the air stream and the yardang bodies. Present study suggests that yardang evolution needs such strong and unidirectional winds in high- or intermediate-energy wind environments. This differs from sandy deserts or sandy lands, which usually develop at low- or intermediate-energy wind environments. Present study clarifies the wind regime corresponding to the long-ridge yardangs' development, and lays firm foundation to put forward the formation mechanisms for yardangs in the Qaidam Basin.
\end{abstract}

Keywords: aeolian landform; yardang; wind regime; drift potential; Qaidam Basin

Citation: GAO Xuemin, DONG Zhibao, DUAN Zhenghu, LIU Min, CUI Xujia, LI Jiyan. 2019. Wind regime for long-ridge yardangs in the Qaidam Basin, Northwest China. Journal of Arid Land, 11(5): 701-712. https://doi.org/ 10.1007/s40333-0190108-4

\section{Introduction}

Yardang is a Uyghur word introduced by Hedin (1903) to define the streamlined hills carved from bedrock or from consolidated or semi-consolidated materials by wind erosion (Ward and Greeley, 1984; Dong et al., 2012a). It is a typical aeolian erosion landform that is widespread in arid and

\footnotetext{
*Corresponding author: GAO Xuemin (E-mail: waipoqiaoqt@163.com)

Received 2019-04-09; revised 2019-08-05; accepted 2019-09-09

C Xinjiang Institute of Ecology and Geography, Chinese Academy of Sciences, Science Press and Springer-Verlag GmbH Germany, part of Springer Nature 2019
} 
semi-arid regions, such as the Qaidam Basin and Taklimakan Desert in China (Xia, 1987; Li et al., 2016a), the Gobi Desert in Mongolia (Ritley and Erdennebat, 2004), the Lut Desert in Iran (Alavipanah et al., 2007; Ehsani and Quiel, 2008), the Um Al-Rimam depression in northern Kuwait (Al-Dousari et al., 2009), the Western Desert in Egypt (Breed et al., 1979; Grolier et al., 1980), the Bodélé Depression in Chad (Bristow et al., 2009), the Ebro Depression in northeastern Spain (Gutiérrez-Elorza et al., 2002), the Rogers Dry Lake in the USA (Ward and Greeley, 1984) and the western coastal desert in South America (Inbar and Risso, 2001; de Silva et al., 2010), as well as the regions on Mars and Venus (Ward, 1977; Trego, 1990, 1992; Greeley et al., 1995; Bridges et al., 2010; Zimbelman and Griffin, 2010), and possibly on Titan (Paillou et al., 2016). Comparative researches on terrestrial yardangs and their Martian counterparts have become increasingly popular in recent years (de Silva et al., 2010; Zimbelman and Griffin, 2010; Wang et al., 2018). Yardangs bear rich information on their Martian aeolian history and provide important insights into geomorphic development of the Martian surface (Laity, 2009). Though yardangs are found at the margin of most major deserts around the world, they nevertheless cover only a small percentage of Earth's land surface.

There are still much dispute remains to be determined about the formation mechanisms of yanrdangs (Laity, 2009). Yardangs are sculpted by a combination of aeolian erosion, fluvial erosion, weathering, mass movement and corrosion (Laity, 2009; Dong et al., 2012a). Aeolian erosion includes abrasion and deflation, of which abrasion by saltating sand particles is probably the dominant process in the formation of yardangs (Goudie, 2007). Although suspended particles have relatively low kinetic energy, they can reach significant heights above the ground surface and also play an important role in sculpting yardangs (Dong et al., 2012a). Deflation of loose sediments caused by aeolian abrasion and weathering can expose new rock surfaces to further abrasion and accelerating yardang formation. And deflation may play a particularly important role in poorly indurated lacustrine material (Laity, 2009, 2011). The role of fluvial erosion in sculpting yardangs has long been noticed by geographers, who attributed the formation of yardangs to initial erosion by running water, followed by wind erosion (Hedin, 1903; Xia, 1987). Physical weathering caused by dramatic temperature variations in arid and hyper-arid regions creates fractures on the rock surface, which facilitate subsequent action of exogenous forces. Aeolian abrasion and fluvial erosion of underlying soft and loose sediments can lead to collapse of the overlying strata. Yardang sediments are usually bonded tightly by salts and form a hard crust that is resistant to wind erosion. However, rainfall and running water can dissolve the salts and disintegrate the crust. The greater the salt content, the more significant the corrosion (Dong et al., 2012a). In practice, different combinations of these processes may operate together in different environments.

The yardang fields of Qaidam Basin is the largest and is with the highest elevation in China (Kapp et al., 2011). Fan (1962) studied the landforms near Lenghu town in the northern Qaidam Basin and identified three types of yardangs: pyramid, long-ridge and streamlined whaleback. Following this work, Halimov and Fezer (1989) further classified yardangs into eight types and proposed a comprehensive evolutionary sequence for yardangs in the Qaidam Basin based on the factors that control their evolution during different stages. Wang et al. (2011) constructed a model for evaluating the abrasion rate of yardangs in the western Qaidam Basin and found that the rate ranged from 0.011 to $0.398 \mathrm{~mm} / \mathrm{a}$ between 1986 and 2010, which was much smaller than the yardangs in the Lop Nor Region (Xia, 1987), but agreed with the bedrock incision rate calculated by the cosmogenic ${ }^{10} \mathrm{Be}$ method in the Qaidam Basin (Rohrmann et al., 2013). Li and Dong (2011) and $\mathrm{Li}$ et al. (2012, 2013, 2016a) investigated the sediment characteristics, wind regime, distribution and morphological characteristics of yardangs in the Qaidam Basin. These studies discussed the aeolian environments and the other factors influencing the development of yardangs in the Qaidam Basin.

However, these studies covered only a small portion of the Qaidam Basin. Hu et al. (2017) studied the yardang geometries throughout the western Qaidam Basin and discussed the potential geologic, topographic and wind regime factors responsible for the morphological variability. Zhao et al. (2018) proposed an integrated approach to automatically extract yardangs from satellite images and performed spatial analysis of yardangs throughout the basin. They found that most 
yardangs had developed near anticlines and in Pliocene strata. Mao et al. (2018) synthetically investigated the origins of semi-submerged yardangs near the Duck Lake area of the basin. Wang et al. (2018) comprehensively demonstrated the classification, distribution, morphometry and evolution of yardangs throughout the basin and compared them with yardangs on Mars. Based on the orientation of yardangs and dunes, $\mathrm{Wu}$ et al. (2018) reconstructed the palaeo-wind regime during the Late Holocene in the Qaidam Basin and found that the yardangs and dunes in the eastern basin represented the westerly during the Last Glacial Maximum, while the aeolian landforms in the central and western part represented the northwesterly Asian winter monsoon.

As a typical aeolian erosion landform, wind plays an important role in the development of yardangs. The goal of present study is to clarify the aeolian environments that affect the development of long-ridge yardangs in the northwestern Qaidam Basin. In order to demonstrate the influence of wind regime variation to the formation of aeolian landforms, this paper compares the wind regimes in the northwestern, central-southern, and southeastern Qaidam Basin and the corresponding aeolian landforms.

\section{Materials and methods}

\subsection{Study area}

The Qaidam Basin, which covers an area of $12 \times 10^{4} \mathrm{~km}^{2}$, is the largest sedimentary Cenozoic and intermontane basin on the northeastern Tibetan Plateau. It is enclosed by the Altun Mountains in the northwest, Qilian Mountains in the northeast, the Qimantag Mountains in the southwest and Kunlun Mountains in the southeast. The elevations of these mountains reach 4000 to $5000 \mathrm{~m}$ a.s.l., versus $2800 \mathrm{~m}$ a.s.1. for the interior of the basin (Fig. 1a). The Cenozoic sediments from the surrounding mountains have formed deposits as thick as $12 \mathrm{~km}$, mostly in the form of alluvialfluviolacustrine-playa facies (Xia et al., 2001). These sediments have been reworked by wind to form vast yardang fields, gravel deserts (gobis), playas and salt crusts, saline lakes and salt marshes, and dune fields widely distributed throughout the basin ( $\mathrm{Li}$ et al., 2015, 2016b). The basin is characterized by a convergent drainage system pattern, with rivers that originate from the surrounding mountains and feed saline lakes in the central basin. The basin is characterized by a hyper-arid climate, with mean annual precipitation ranging from $100 \mathrm{~mm}$ in the southeast to less than $20 \mathrm{~mm}$ in the northwest. But the potential mean annual evaporation is much greater in the Qaidam Basin, which can achieve 2000-2500 $\mathrm{mm}$ in the southeastern part and exceed $3000 \mathrm{~mm}$ in the northwestern part. The mean annual precipitation at Lenghu town is $15.8 \mathrm{~mm}$, and the mean annual gale days (wind speed $\geq 17 \mathrm{~m} / \mathrm{s}$ at $10 \mathrm{~m}$ above ground surface) are $55 \mathrm{~d}$ during 1957-2000, with the annual dust storm days range between 3-16 d during the corresponding years (Qiang et al., 2007).

In the present study, we focused on the northwestern Qaidam Basin near Lenghu town (Fig. 1a). The typical long-ridge yardangs distributed in this region are bounded on the west and east by the Chahansilatu and Kunteyi playas and on the north by the Eboliang anticline (Fig. 1b). The playas consist mainly of late Pleistocene to Holocene sediments, whereas the top parts of the Eboliang anticline consist of late-Pliocene to early-Quaternary strata that are mostly siltstone and calcareous mudstone and marl, intercalated with gypsum and salt beds (Tuo and Philp, 2003). The orientation of the long-ridge yardangs is nearly NNW (north-northwest)-SSE (south-southeast), with the longest ridges running more than $1 \mathrm{~km}$ and parallel with each other (Li et al., 2016a; Fig. 1b).

However, a transection through the inter-yardang corridor shows distinctive morphology surrounding WT01, a wind tower installed about $30 \mathrm{~km}$ west of Lenghu town which can automatically record the wind speed and direction of the field. The long-ridge yardangs are only 2-3 $\mathrm{m}$ tall and the inter-yardang corridors are V-shaped, with slopes of $40^{\circ}-50^{\circ}$ on the flanks (Fig. $2 a)$ in the north of WT01. The inter-yardang corridors are much shallower and free of loose detrital sediments. South of WT01, severe incision and lateral erosion of the yardangs have occurred, creating inter-yardang corridors with a deep U-shape (Fig. 2b). The yardang height can attain 6-7 $\mathrm{m}$, and the inter-yardang corridors often contain layers of aeolian sands. 

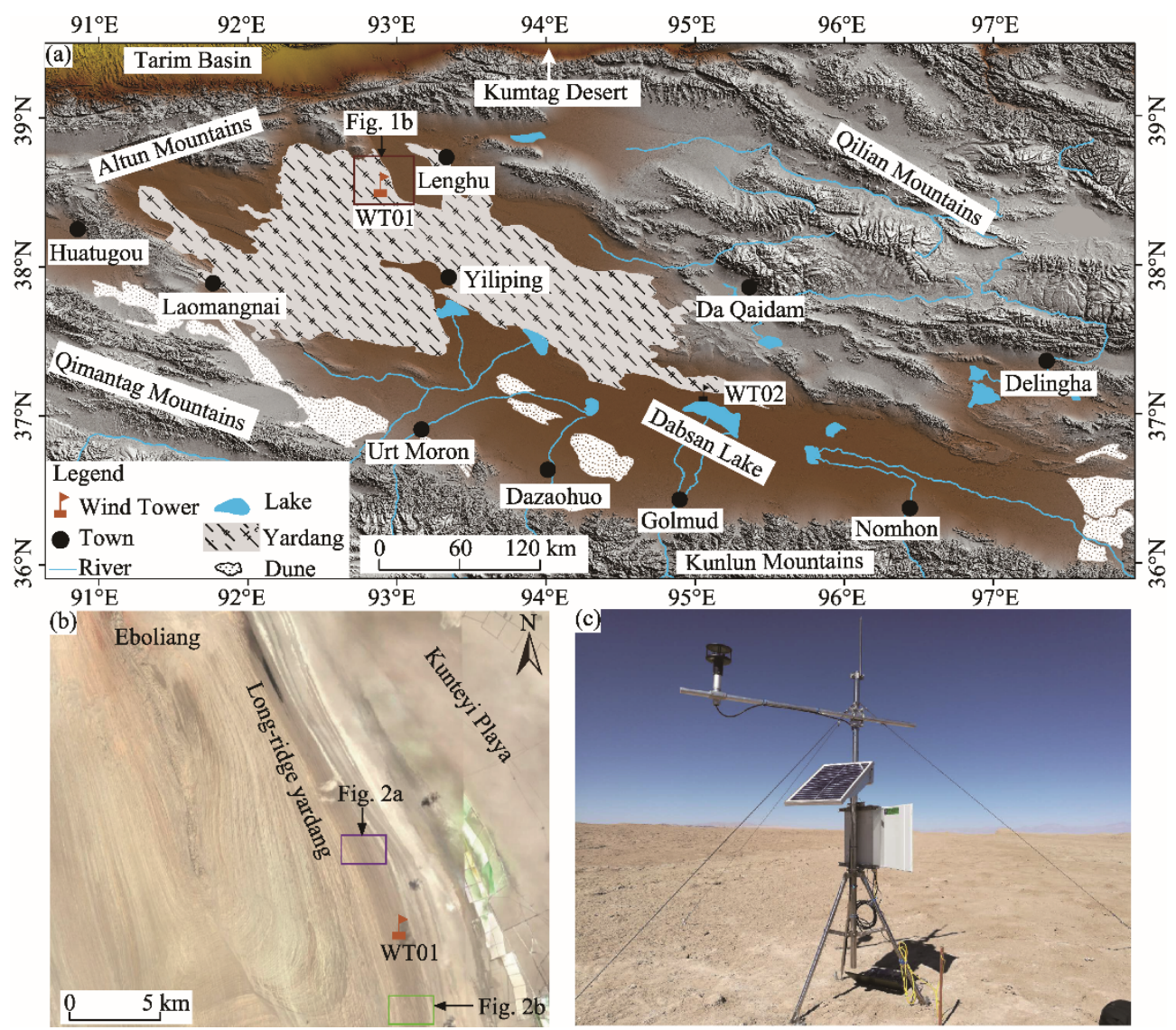

Fig. 1 (a) Location and physiographic setting of the Qaidam Basin, and the location of wind observation tower and yardangs; (b) Google Earth image of the landforms surrounding wind tower WT01; (c) The ground surface characteristics surrounding the wind observation tower WT01 $\left(38^{\circ} 37^{\prime} 13^{\prime \prime} \mathrm{N}, 92^{\circ} 56^{\prime} 57^{\prime \prime} \mathrm{E}\right)$.
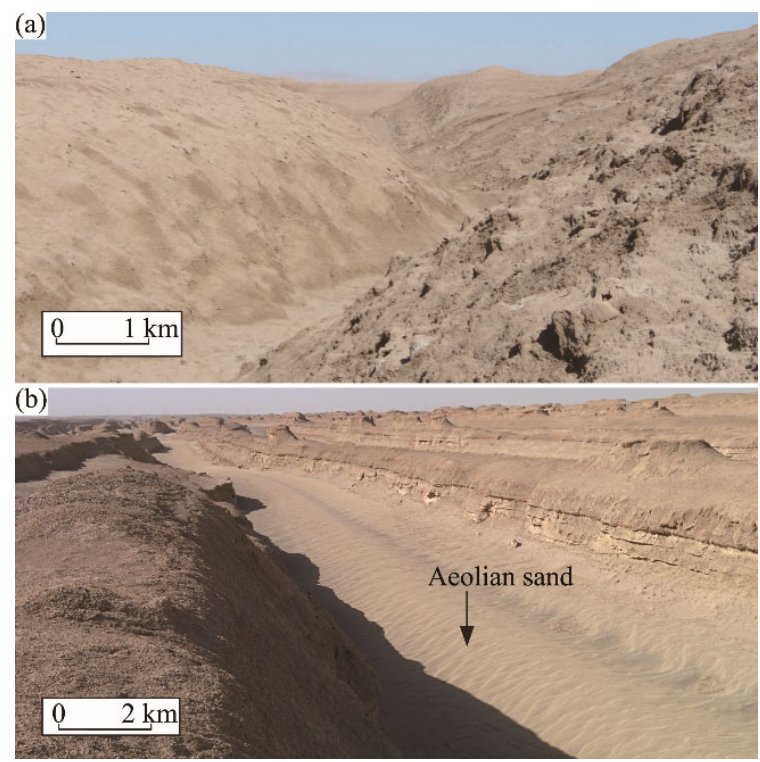

Fig. 2 Yardangs on the (a) upwind (north) and (b) downwind (south) direction of wind tower WT01. Note that the cross-section of the inter-yardang corridors in the upwind direction shows a V-shape, versus a U-shape in the downwind direction. Upwind, the corridors are largely free of loose sediments, whereas aeolian sands are common in the downwind corridors. 


\subsection{Wind data collection and analysis}

To obtain the wind regime data, we installed a Windsonic 2-axis ultrasonic anemometer (Gill Instruments, UK; WT01) on a mast $2 \mathrm{~m}$ above the ground. This instrument can automatically record the wind speed and direction at 10-min intervals. Data were stored in a CR300 data logger (Campbell Scientific, Inc., Canada). The ground surface surrounding the wind tower WT01 is flat (Fig. 1c), in accordance with China's national standards for meteorological station installation. The wind speed measured at $2 \mathrm{~m}$ above the ground was transformed to the speed at $10 \mathrm{~m}$ above the ground using Equation 1 (Dong et al., 2012b):

$$
U_{10}=0.17+1.08 U_{2},
$$

where $U_{10}$ and $U_{2}$ are the wind velocities measured at 10 and $2 \mathrm{~m}$ (in knots) above the ground, respectively. The correlation coefficient was $R^{2}=1.00$ at a significance level of $P<0.01$. Among all winds, only sand driving winds (i.e., winds that exceed the threshold wind speed) are effective in shaping aeolian landforms. The threshold of wind speed for entrainment of local sediments was 6 $\mathrm{m} / \mathrm{s}$ at the height of $10 \mathrm{~m}$. We used wind data from December 2017 to November 2018 to calculate the drift potential (DP) and associated parameters according to Fryberger and Dean (1979), and Pearce and Walker's (2005) modified wind speed classes.

$$
\begin{gathered}
\mathrm{DP}=U_{10}^{2}\left(U_{10}-U_{t}\right) t, \\
\mathrm{RDD}=\operatorname{Arctan}(C / D), \\
C=\sum(\mathrm{VU}) \sin (\theta), \\
D=\sum(\mathrm{VU}) \cos (\theta), \\
\mathrm{RDP}=\sqrt{C^{2}+D^{2}},
\end{gathered}
$$

where DP is expressed in vector units (VU); $U_{10}$ is the 10 -min average wind speed at a height of $10 \mathrm{~m}$ (in knots); $U_{t}$ is the threshold wind speed at the same height as $U_{10}$ (in knots); $t$ is the proportion of the time during which the wind speed is greater than the threshold speed; RDD is the resultant drift direction, which represents the net sand drift direction based on winds from these 16 compass directions $\left({ }^{\circ}\right) ; \theta$ is the mid-point of orientation classes $\left({ }^{\circ}\right)$; and RDP is the resultant drift potential (VU), which expresses the net DP from 16 compass directions.

RDP/DP represents the directional variability. To compare wind regimes and their impact on aeolian landform development, we used data from the WT02 station $\left(38^{\circ} 08^{\prime} 09^{\prime \prime} \mathrm{N}, 95^{\circ} 06^{\prime} 42^{\prime \prime} \mathrm{E}\right.$; Fig. 1a), which was on the northern margin of Dabsan Lake and characterized by typical whaleback yardangs. The data for that station were obtained from Li et al. (2013).

\section{Results}

\subsection{Wind direction and speed}

The long-ridge yardang field in the northwestern Qaidam Basin was dominated by NNW and NW (northwest) winds, which accounted for $43.13 \%$ and $18.00 \%$ of the annual total wind records, respectively. Northerly winds are in the third place, with $9.01 \%$ of the total. Winds from the other directions accounted for less than $30 \%$ of the total, with almost all of these winds below the threshold wind speed. Therefore, the sand-driving winds in the study area are mainly from the NNW, NW and N (north) directions, which combined account for $99.21 \%$ of the annual total sanddriving winds (Fig. 3).

The monthly average wind speed in the study area was $4.82 \mathrm{~m} / \mathrm{s}$, with a maximum of $6.73 \mathrm{~m} / \mathrm{s}$ in August and a minimum of $2.52 \mathrm{~m} / \mathrm{s}$ in December. The monthly average wind speed is much smaller in winter, and increases during the spring until it attains a maximum in summer, then decreases gradually in autumn. The monthly maximum wind speed ranges from 16.51 to $20.45 \mathrm{~m} / \mathrm{s}$, with a mean of $18.17 \mathrm{~m} / \mathrm{s}$. The variation of the monthly maximum wind speed differs from that of the monthly average wind speed, with the maximum value in November, and the minimum value 
in September. The frequency of sand-driving winds shows similar variation to the monthly average wind speed, with a minimum frequency of $1.57 \%$ in December and gradually increasing in spring to reach a maximum of $14.47 \%$ in August, then gradually decreasing in autumn (Fig. 4). The high frequency of sand-driving winds in summer can be attributed to the high temperatures during the months, which can increase atmospheric instability and lead to downward momentum transfer and active local convection ( $\mathrm{Li}, 2003)$.

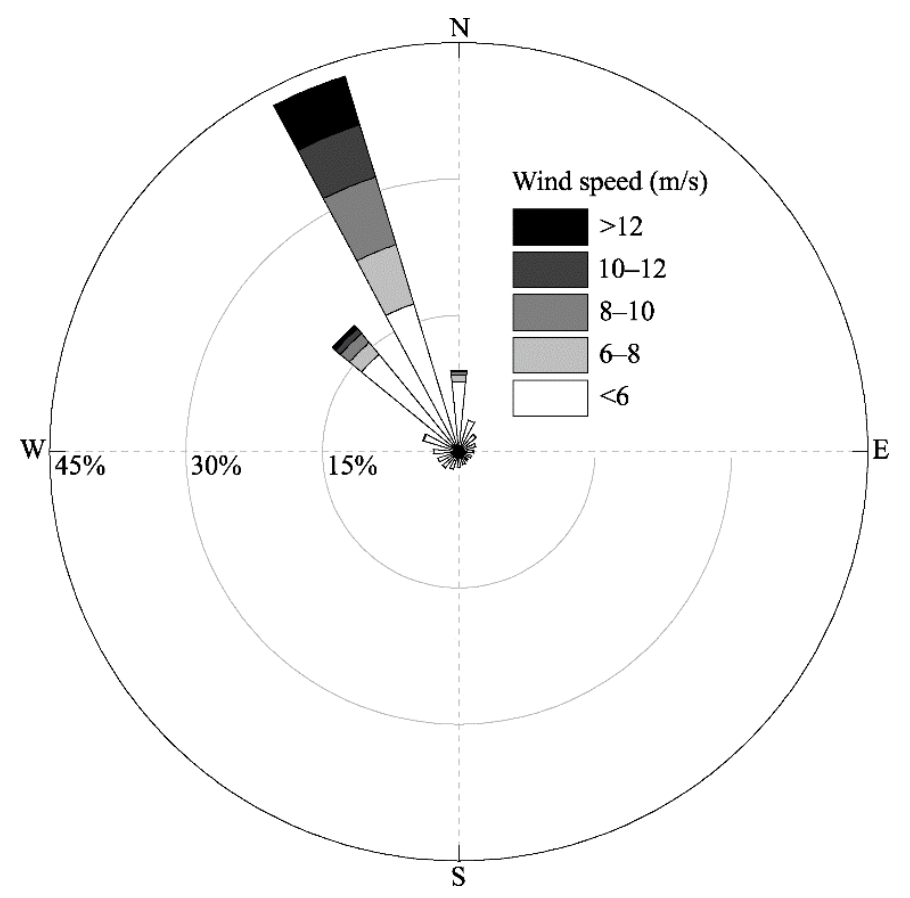

Fig. 3 Annual wind rose for the long-ridge yardangs

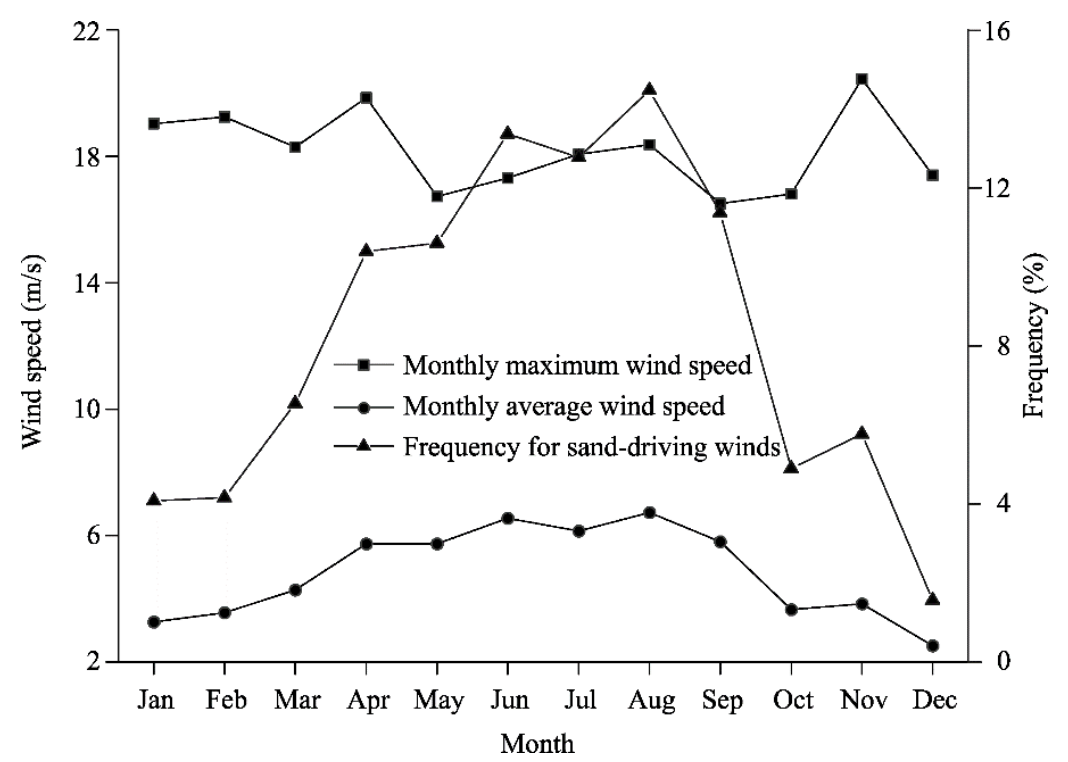

Fig. 4 Monthly maximum and average wind speeds and monthly frequency of sand-driving winds

\subsection{Drift potential}

Table 1 summarizes the characteristics of the wind regime in the Fryberger and Dean (1979) system. Corresponding to the variation of the sand-driving winds, DP and RDP are the largest in summer, 
reaching 479.73 and $475.03 \mathrm{VU}$, respectively. DP and RDP are slightly smaller in spring than in summer, with values of 409.57 and $404.55 \mathrm{VU}$, respectively. DP and RDP are much smaller in autumn and winter than in spring and summer (Fig. 5). The annual DP and RDP totaled 1246.05 and $1231.86 \mathrm{VU}$, respectively, which are probably the largest values reported in Chinese desert regions. Both indicate a high-energy wind environment. The annual RDD for the study region changes little among seasons and remains around $156.00^{\circ}$ (SSE). RDP/DP is close to 1 in all seasons, which represents a narrow unimodal wind regime (Fig. 6). To clarify the role of this wind regime in formation and evolution of the long-ridge yardangs, we manually measured the orientation of 425 yardangs in Google Earth images of our study area (Fig. 6). This analysis shows that the orientation of the long-ridge yardangs closely parallels with the RDD, which indicates that wind is likely to be the dominant exogenous agent responsible for sculpting of the yardangs.

Table 1 Classification of wind energy environments using the system of Fryberger and Dean (1979)

\begin{tabular}{ccccc}
\hline DP $(\mathrm{VU})$ & Wind energy environment & RDP/DP & Directional variability & Probable wind regime \\
\hline$<200$ & Low & $<0.3$ & High & Complex or obtuse bimodal \\
$200-400$ & Intermediate & $0.3-0.8$ & Intermediate & Obtuse or acute bimodal \\
$>400$ & High & $>0.8$ & Low & Wide or narrow unimodal \\
\hline
\end{tabular}

Note: DP, drift potential; RDP, resultant drift potential; RDP/DP, directional variability.

(a) Winter

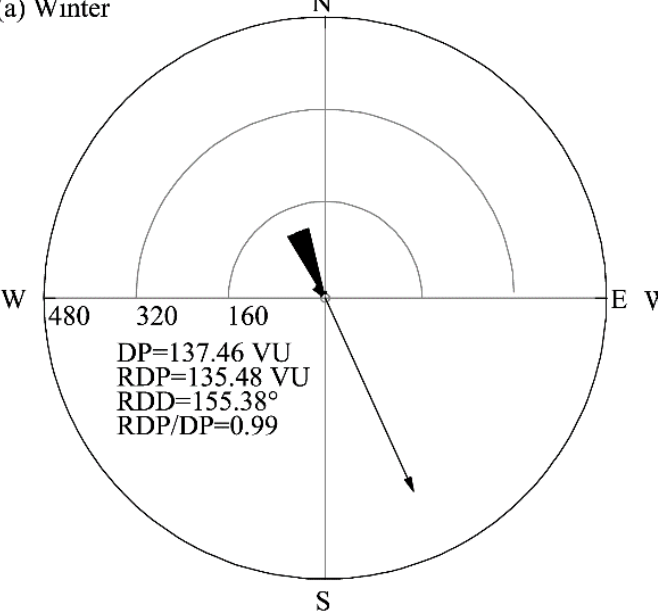

(c) Summer

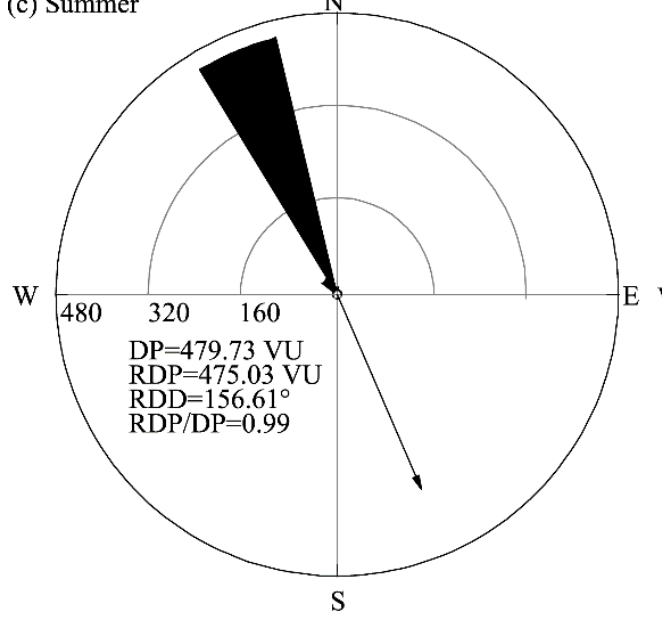

(b) Spring

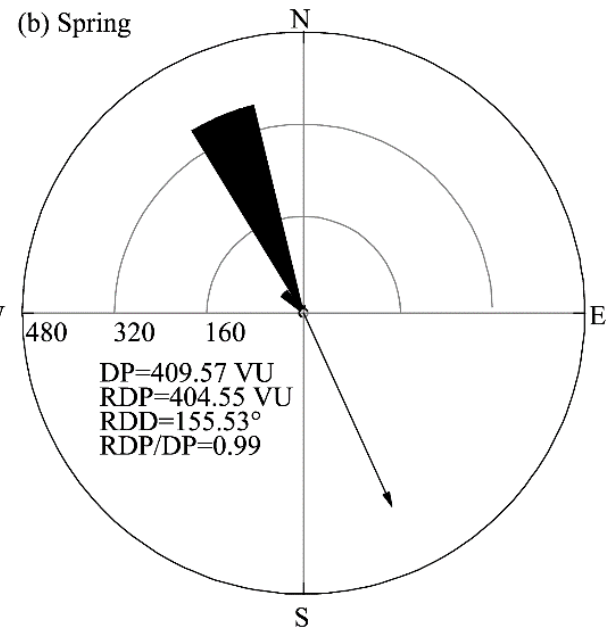

(d) Autumn

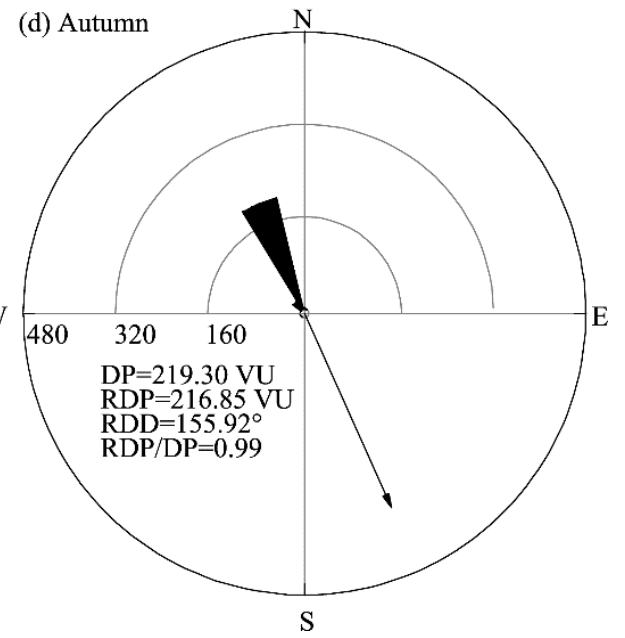

Fig. 5 Seasonal drift potential (DP) and related parameters for the long-ridge yardangs. RDP, resultant drift potential; RDD, resultant drift direction; RDP/DP, directional variability. The solid arrow indicate the RDD. 


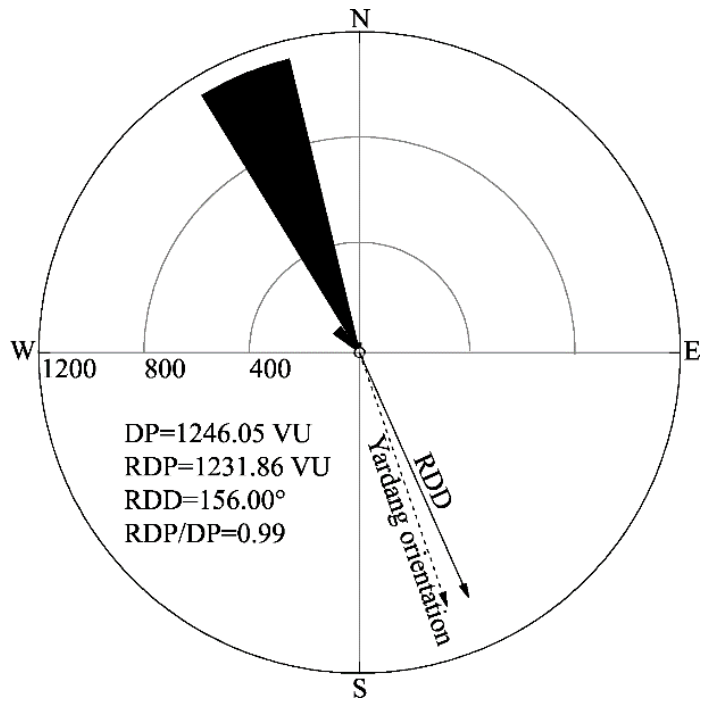

Fig. 6 Annual DP and related parameters for the long-ridge yardangs. The solid arrow indicates RDD, and the dotted arrow indicates the average orientation of the long-ridge yardangs determined from Google Earth images.

\section{Discussion}

The long-ridge yardangs in the northwestern Qaidam Basin formed under a narrow unimodal wind regime, with the effective winds mainly blowing from the NNW (Fig. 7a). Compared with the longridge yardangs, typical whaleback yardangs at the northern margin of Dabsan Lake in the central-
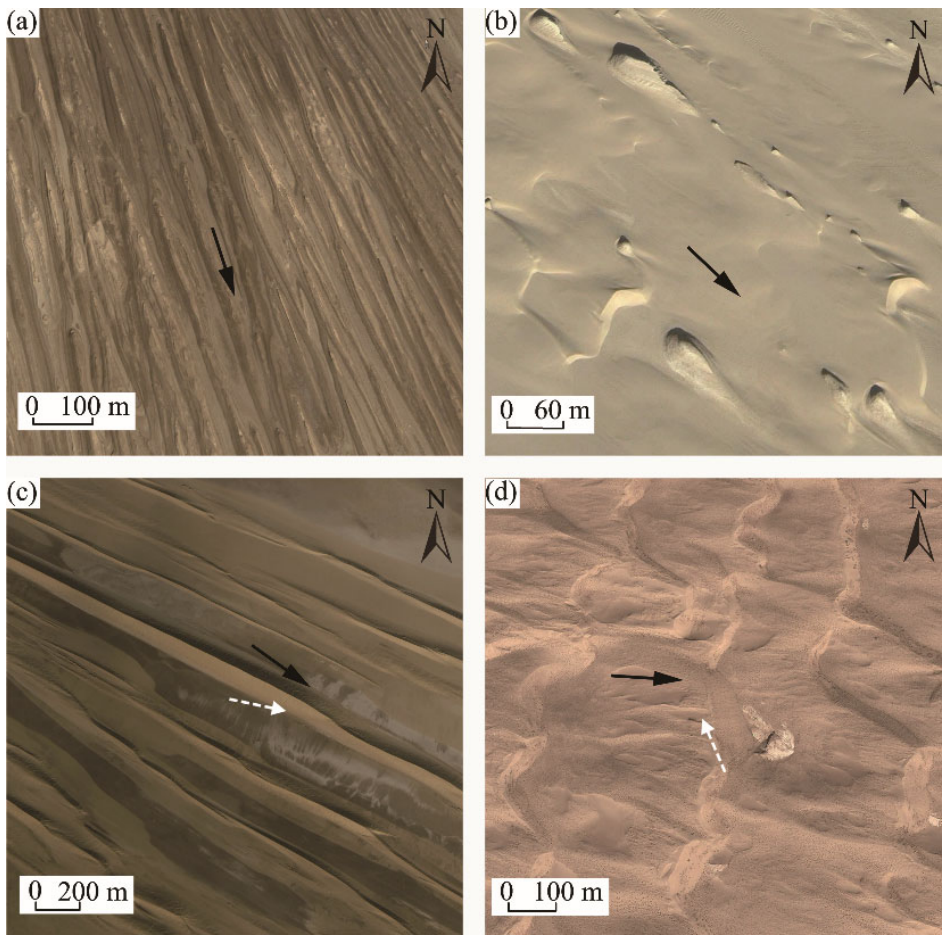

Fig. 7 Google Earth images of the major aeolian landforms in the Qaidam Basin. The solid black arrow indicate the prevailing wind direction, and the dashed white arrow indicates a secondary wind direction inferred from the aeolian landforms. (a), Long-ridge yardangs at 38 $35^{\prime} 11^{\prime \prime} \mathrm{N}, 92^{\circ} 57^{\prime} 07^{\prime \prime} \mathrm{E}$; (b), Whale-back yardangs accompanied by barchan dunes at $37^{\circ} 11^{\prime} 44^{\prime \prime} \mathrm{N}, 95^{\circ} 09^{\prime} 47^{\prime \prime} \mathrm{E}$; (c), Linear dunes at $37^{\circ} 07^{\prime} 19^{\prime \prime} \mathrm{N}, 95^{\circ} 20^{\prime} 52^{\prime \prime} \mathrm{E}$; and (d), Dune networks at $36^{\circ} 20^{\prime} 41^{\prime \prime} \mathrm{N}, 97^{\circ} 47^{\prime} 26^{\prime \prime} \mathrm{E}$. 
south Qaidam Basin (Fig. 1a) evolved under an intermediate-energy wind environment with a wide unimodal wind regime. The barchan dunes downwind of the typical whaleback yardangs developed under an intermediate-energy wind environment with a narrow unimodal wind regime (Fig. $7 \mathrm{~b} ; \mathrm{Li}$ et al., 2013). The linear dunes in the same area also formed under an intermediate-energy wind environment, but with a wide unimodal wind regime (Fig. 7c; Bao et al., 2015). Therefore, wind energy in the Qaidam Basin decreases from the northwest to the central-south, with a transition from high to intermediate. Under the influence of the topography surrounding the basin, the $\mathrm{N}$ winds in the northwestern basin gradually turn towards $\mathrm{W}$ winds in the central-southern basin, leading to a transition from a narrow unimodal wind regime to a wide unimodal wind regime. At the southeastern edge of the Qaidam Basin, where SW (southwest) winds arise, a large area of network dune fields has formed (Fig. 7d). Hence, with the wind regime complexity increases from the central-southern to southeastern Qaidam Basin, the corresponding dune forms are transformed from simple barchan and linear dunes to compound network dunes.

Table 2 compares the wind regime of the long-ridge yardangs in the northwestern Qaidam Basin in the present study with the wind regimes in other regions where yardangs or other aeolian landforms exist. Except the Bayan Nur in the Badain Jaran Desert, which pertains to a high-energy wind environment, the other compared regions all have an intermediate- or low-energy wind environment, which agrees with Lancaster (2013), who reported that the world's major sand seas have low-energy wind environments. In addition, most of these compared regions have bimodal or

Table 2 Wind regime of Qaidam Basin and other desert regions in northern China

\begin{tabular}{|c|c|c|c|c|c|c|c|c|}
\hline \multicolumn{2}{|c|}{ Location } & \multirow{2}{*}{$\frac{\mathrm{DP}(\mathrm{VU})}{1246.05}$} & \multirow{2}{*}{$\frac{\text { WE }}{\text { High }}$} & \multirow{2}{*}{$\frac{\text { RDP (VU) }}{1231.86}$} & \multirow{2}{*}{$\frac{\operatorname{RDD}\left(^{\circ}\right)}{156.00}$} & \multirow{2}{*}{$\begin{array}{c}\mathrm{RDP} / \mathrm{DP} \\
0.99\end{array}$} & \multirow{2}{*}{$\frac{\mathrm{DC}}{\text { Narrow unimodal }}$} & \multirow{2}{*}{$\begin{array}{c}\text { Reference } \\
\text { Present study }\end{array}$} \\
\hline WT01 & $\begin{array}{l}\text { NW Qaidam } \\
\text { Basin }\end{array}$ & & & & & & & \\
\hline WT02 & SE Qaidam Basin & 326.00 & Intermediate & 235.00 & 110.14 & 0.72 & Wide unimodal & Li et al. (2013) \\
\hline Kumtag & Northern & 363.35 & Intermediate & 192.37 & 215.00 & 0.53 & Obtuse bimodal & Dong et al. (2012b) \\
\hline \multirow[t]{3}{*}{ Desert } & Western & 216.96 & Intermediate & 83.72 & 220.00 & 0.39 & Obtuse bimodal & Dong et al. (2012b) \\
\hline & Southern & 162.39 & Low & 94.67 & 153.00 & 0.58 & Obtuse bimodal & Dong et al. (2012b) \\
\hline & Eastern & 232.72 & Intermediate & 127.78 & 115.00 & 0.55 & Complex & Dong et al. (2012b) \\
\hline Badain Jaran & Ejin Banner & 90.60 & Low & 68.50 & 117.30 & 0.76 & Obtuse bimodal & Zhang et al. (2015a) \\
\hline \multirow[t]{3}{*}{ Desert } & Dingxin & 116.40 & Low & 65.20 & 153.90 & 0.56 & Obtuse bimodal & Zhang et al. (2015a) \\
\hline & $\begin{array}{l}\text { Alagxa Right } \\
\text { Banner }\end{array}$ & 286.30 & Intermediate & 161.00 & 310.60 & 0.56 & Obtuse bimodal & Zhang et al. (2015a) \\
\hline & Bayan Nur & 448.20 & High & 275.60 & 121.60 & 0.61 & Complex & Zhang et al. (2015a) \\
\hline Tengger & Shapotou & 357.43 & Intermediate & 164.42 & 134.19 & 0.46 & Obtuse bimodal & Zhang et al. (2008) \\
\hline \multirow[t]{2}{*}{ Desert } & Jiahe & 195.14 & Low & 118.94 & 102.00 & 0.62 & Acute bimodal & Zhang et al. (2015b) \\
\hline & Wujiajing & 37.91 & Low & 34.98 & 143.00 & 0.93 & Narrow unimodal & Zhang et al. (2015b) \\
\hline Gurbantunggut & Central & 66.70 & Low & 25.70 & 197.00 & 0.39 & Complex & Guo et al. (2011) \\
\hline Desert & Southern & 29.80 & Low & 16.30 & 108.40 & 0.55 & Obtuse bimodal & Guo et al. (2011) \\
\hline Taklamakan & Kuqa & 34.80 & Low & 15.00 & 193.40 & 0.43 & Complex & $\mathrm{Zu}$ et al. (2005) \\
\hline \multirow[t]{5}{*}{ Desert } & Markit & 43.20 & Low & 27.40 & 164.60 & 0.63 & Acute bimodal & $\mathrm{Zu}$ et al. (2005) \\
\hline & Hotan & 44.10 & Low & 40.50 & 102.80 & 0.92 & Narrow unimodal & $\mathrm{Zu}$ et al. (2005) \\
\hline & Tikanlik & 95.60 & Low & 89.60 & 246.50 & 0.94 & Narrow unimodal & $\mathrm{Zu}$ et al. (2005) \\
\hline & Ruoqiang & 399.00 & Intermediate & 319.00 & 235.90 & 0.80 & Narrow unimodal & $\mathrm{Zu}$ et al. (2005) \\
\hline & Tazhong & 114.50 & Low & 67.00 & 231.50 & 0.59 & Acute bimodal & $\mathrm{Zu}$ et al. (2005) \\
\hline \multicolumn{2}{|c|}{ Hulun Buir Sandy Land } & 279.10 & Intermediate & 161.20 & 148.30 & 0.58 & Obtuse bimodal & $\begin{array}{l}\text { Wang and Hasi } \\
\qquad(2008)\end{array}$ \\
\hline \multicolumn{2}{|c|}{ Horqin Sandy Land } & 70.50 & Low & 37.89 & 108.30 & 0.54 & Obtuse bimodal & Yang et al. (2016) \\
\hline \multicolumn{2}{|c|}{ Mu Us Sandy Land } & 66.75 & Low & 34.04 & 146.00 & 0.51 & Obtuse bimodal & Pang et al. (2019) \\
\hline
\end{tabular}

Note: DP, drift potential; WE, wind energy; RDP, resultant drift potential; RDD, resultant drift direction; RDP/DP, directional variability; $\mathrm{DC}$, direction category. 
complex wind regimes. The distinctive difference of wind regimes between the long-ridge yardangs and the compared regions also suggests that yardang formation requires strong and unidirectional winds (Goudie, 2007). Strong winds from the Tarim Basin and Kumtagh Desert overflowed the passing aisle in the Altun Mountains and later descend to form an extremely dry foehn when they enter the Qaidam Basin (Halimov and Fezer, 1989). This descending wind sculpted the initial pluvial-alluvial plains and playa surfaces of our study area, and gradually sculpted the large longridge yardang fields in the northwestern Qaidam Basin. Subsequently, the interaction between the wind and the long-ridge yardangs created a funneling effect that both concentrated and strengthened the air stream in the inter-yardang corridors. This would have caused RDP/DP to evolve towards the value of 1.00 .

\section{Conclusions}

In this study, we analyzed the wind regime (speed and direction) for long-ridge yardangs in the northwestern Qaidam Basin and compared it with the other regions. We found that the sand-driving winds mainly blew from the NNW, NW and N directions, and were the severest in summer and spring. Annual DP and RDP/DP indicate that the study area pertains to an extremely high-energy wind environment and a narrow unimodal wind regime. The strong and unidirectional wind regime that created and subsequently shaped the long-ridge yardangs in the northwestern Qaidam Basin can be attributed to a combination of the topographic obstacle created by the Altun Mountains and interactions between the descending air stream that passes over these mountains and the yardang bodies. Yardangs in the Qaidam Basin have developed under a high- and intermediate-energy wind environment, which differs from the environment in most Chinese sandy deserts or sandy lands, which are generally controlled by low- or intermediate-energy wind environments.

\section{Acknowledgements}

This research was supported by the National Natural Science Foundation of China (41601005), and the Key Laboratory of Education Ministry on Environment and Resources in Tibetan Plateau (2018-QHS-K08). We thank the anonymous reviewers for their constructive suggestions and insightful comments on our paper.

\section{References}

Alavipanah S K, Saragjian M, Savaghebi G R, et al. 2007. Land surface temperature in the yardang region of Lut Desert (Iran) based on field measurements and Landsat thermal data. Journal of Agricultural Science and Technology, 9(4): $287-303$.

Al-Dousari A M, Al-Elaj M, Al-Enezi E, et al. 2009. Origin and characteristics of yardangs in the Um Al-Rimam depressions (N Kuwait). Geomorphology, 104(3-4): 93-104.

Bao F, Dong Z, Zhang Z. 2015. Wind regime in the Qaidam Basin Desert. Journal of Desert Research, 35(3): 549-554. (in Chinese) Breed C S, Grolier M J, McCauley J F. 1979. Eolian features in the Western Desert of Egypt and some applications to Mars. Journal of Geophysical Research: Solid Earth, 84(B14): 8205-8221.

Bridges N T, Banks M E, Beyer R A, et al. 2010. Aeolian bedforms, yardangs, and indurated surface in the Tharsis Montes as seen by the HiRISE camera: evidence for dust aggregates. Icarus, 205(1): 165-182.

Bristow C S, Drake N, Armitage S. 2009. Deflation in the dustiest place on Earth: the Bodélé Depression, Chad. Geomorphology, 105(1-2): 50-58.

de Silva S L, Bailey J E, Mandt K E, et al. 2010. Yardangs in terrestrial ignimbrites: synergistic remote and field observations on Earth with applications to Mars. Planetary and Space Science, 58(4): 459-471.

Dong Z, Lv P, Lu J, et al. 2012a. Geomorphology and origin of yardangs in the Kumtagh Desert, northwest China. Geomorphology, 139-140: 145-154.

Dong Z, Zhang Z, Lv P, et al. 2012b. Analysis of the wind regime in context of dune geomorphology for the Kumtagh Desert, Northwest China. Zeitschrift für Geomorphologie, 56(4): 459-475.

Ehsani A H, Quiel F. 2008. Application of self organizing map and SRTM data to characterize yardangs in the Lut desert, Iran. Remote Sensing of Environment, 112(7): 3284-3294.

Fan X. 1962. Geomorphology of northwestern Qaidam Basin near Lenghu. Acta Geographic Sinica, 28(4): 275-289. (in Chinese ) Fryberger S G, Dean G. 1979. Dune forms and wind regime. In: McKee E D. A Study of Global Sand Seas. United States 
Geological Survey Professional Paper 1052. Honolulu: University Press of the Pacific, 137-169.

Goudie A S. 2007. Mega-yardangs: a global analysis. Geography Compass, 1(1): 65-81.

Greeley R, Bender K, Thomas P E, et al. 1995. Wind-related features and processes on Venus: summary of Magellan results. Icarus, 115(2): 399-420.

Grolier M J, McCauley J F, Breed C S, et al. 1980. Yardangs of the Western Desert. Geological Journal, 146(1): 86-87.

Guo H, Wang X, Jiang J, et al. 2011. Wind regime and its geomorphologic significance in the hinterland of Gurbantonggut Desert. Arid Zone Research, 28(4): 580-585. (in Chinese)

Gutiérrez-Elorza M, Desir G, Gutiérrez-Santolalla F. 2002. Yardangs in the semiarid central sector of the Ebro Depression (NE Spain). Geomorphology, 44(1-2): 155-170.

Halimov M, Fezer F. 1989. Eight yardang types in Central Asia. Zeitschrift für Geomorphologie, 33(2): $205-217$.

Hedin S. 1903. Central Asia and Tibet. New York: Charles Scribner and Sons Press, 1-1272.

Hu C, Chen N, Kapp P, et al. 2017. Yardang geometries in the Qaidam Basin and their controlling factors. Geomorphology, 299: 142-151.

Inbar M, Risso C. 2001. Holocene yardangs in volcanic terrains in the southern Andes, Argentina. Earth Surface Processes and Landforms, 26(6): 657-666.

Kapp P, Pelletier J D, Rohrmann A, et al. 2011. Wind erosion in the Qaidam basin, central Asia: implications for tectonics, paleoclimate, and the source of the Loess Plateau. GSA Today, 21(4-5): 4-10.

Laity J E. 2009. Landforms, landscapes, and processes of aeolian erosion. In: Parsons A J, Abrahams A D. Geomorphology of Desert Environments (2 ${ }^{\text {nd }}$ ed.). Berlin: Springer Press, 597-627.

Laity J E. 2011. Wind erosion in drylands. In: Thomas D S G. Arid Zone Geomorphology: Process, Form and Change in Drylands ( $3^{\text {rd }}$ ed.). New York: John Wiley \& Sons Press, 539-568.

Lancaster N. 2013. Sand seas and dune fields. In: Shroder J F. Treatise on Geomorphology (Vol. 11). San Diego: Academic Press, 219-245.

Li J. 2003. Weather and Meteorology in the Taklimakan Desert and its Surrounding Mountains. Beijing: Science Press, 1-851. (in Chinese)

Li J, Dong Z. 2011. Morphological parameters of yardangs in southeestern Qaidam Basin. Bulletin of Soil and Water Conservation, 31(4): 122-125. (in Chinese)

Li J, Dong Z, Li E, et al. 2012. Grain-size characteristics of the deposits from yardang landforms in the Charhan Salt Lake area. Journal of Desert Research, 32(5): 1187-1192. (in Chinese)

Li J, Dong Z, Li E, et al. 2013. Wind regime of yardang landform regions in the Qarhan Salt Lake. Journal of Desert Research, 33(5): 1293-1298. (in Chinese)

Li J, Dong Z, Zhang Z, et al. 2015. Grain-size characteristics of linear dunes on the northern margin of Qarhan Salt Lake, northwestern China. Journal of Arid Land, 7(4): 438-449.

Li J, Dong Z, Qian G, et al. 2016a. Yardangs in the Qaidam Basin, northwestern China: distribution and morphology. Aeolian Research, 20: 89-99.

Li J, Dong Z, Qian G, et al. 2016b. Pattern analysis of a linear dune field on the northern margin of Qarhan Salt Lake, northwestern China. Journal of Arid Land, 8(5): 670-680.

Mao X, Liu X, Dong Y, et al. 2018. Research on the genesis of semi-submerged yardang landform in the Duck Lake area of Qaidam Basin. Geological Review, 64(6): 1505-1518. (in Chinese)

Paillou P, Seignovert B, Radebaugh J, et al. 2016. Radar scattering of linear dunes and mega-yardangs: application to Titan. Icarus, 270: 211-221.

Pang Y, Wu B, Jia X, et al. 2019. Characteristics of wind regime and drift potential in Mu Us Sandy Land. Journal of Desert Research, 39(1): 62-67. (in Chinese)

Pearce K I, Walker I J. 2005. Frequency and magnitude biases in the 'Fryberger' model, with implications for characterizing geomorphically effective winds. Geomorphology, 68(1-2): 39-55.

Qiang M, Xiao S, Zhang J, et al. 2007. Impact of wind velocity on dustfall during dust storm events in northern Qaidam Basin, China. Journal of Desert Research, 27(2): 290-295. (in Chinese)

Ritley K, Erdennebat O. 2004. Yardangs and dome dunes northeast of Tavan Har, Gobi, Mongolia. Geological Society of America, 36(4): 33-36.

Rohrmann A, Heermance R, Kapp P, et al. 2013. Wind as the primary driver of erosion in the Qaidam Basin, China. Earth and Planetary Science Letters, 374: 1-10.

Trego K D. 1990. The absence of yardangs on Venus. Earth, Moon, and Planet, 49(3): 283-284.

Trego K D. 1992. Yardang identification in Magellan imagery of Venus. Earth, Moon, and Planet, 58(3): $289-290$. 
Tuo J, Philp R P. 2003. Occurrence and distribution of high molecular weight hydrocarbons in selected non-marine source rocks from the Liaohe, Qaidam and Tarim Basins, China. Organic Geochemistry, 34(11): 1543-1558.

Wang J, Xiao L, Reiss D, et al. 2018. Geological features and evolution of yardangs in the Qaidam Basin, Tibetan Plateau (NW China): a terrestrial analogue for Mars. Journal of Geophysical Research: Planets, 123(9): 2336-2364.

Wang S, Hasi E. 2008. Wind regime and blowouts geomorphology in Hulun Buir Sandy Grassland. Research of Soil and Water Conservation, 15(3): 74-76, 80. (in Chinese)

Wang Z, Wang H, Niu Q, et al. 2011. Abrasion of yardangs. Physical Review E, 84(3): 031304, doi: 10.1103/PhysRevE.84.031304.

Ward A W. 1977. Yardangs on Mars: evidence of recent wind erosion. Journal of Geophysical Research: Solid Earth, 84(B14): 8147-8166.

Ward A W, Greeley R. 1984. Evolution of the yardangs at Rogers Lake, California. Bulletin of the Geological Society of America, 95(7): 829-837.

Wu T, Li J, Yang M. 2018. The aeolian bedforms and the reconstruction of late Holocene wind direction in Qaidam Basin. Acta Scientiarum Naturalium Universitatis Pekinensis, 54(5): 1021-1027. (in Chinese)

Xia W, Zhang N, Yuan X, et al. 2001. Cenozoic Qaidam Basin, China: a stronger tectonic inversed, extensional rifted basin. American Association of Petroleum Bulletin, 85(4): 715-736.

Xia X C. 1987. Formation of the yardangs in Lop Nor region. In: Xia X C. Scientific Expedition in Lop Nor. Beijing: Science Press, 52-59. (in Chinese)

Yang L, Han G, Luo Y, et al. 2016. The intensity of sand drift activities in spring in the downstream of the Laoha River, China. Journal of Arid Land Resources and Environment, 30(11): 174-179. (in Chinese)

Zhang K, Zu R, Qu J, et al. 2008. Relationship between sand drift potential and maximum possible sand transport in southeast of Tengger Desert. Journal of Desert Research, 28(4): 605-610. (in Chinese)

Zhang Z, Dong Z, Li C. 2015a. Wind regime and sand transport in China's Badain Jaran Desert. Aeolian Research, 17 : 1-13.

Zhang Z, Dong Z, Wen Q, et al. 2015b. Wind regimes and aeolian geomorphology in the western and southwestern Tengger Desert, NW China. Geological Journal, 50(6): 707-719.

Zhao Y, Chen N, Chen J, et al. 2018. Automatic extraction of yardangs using Landsat 8 and UAV images: a case study in the Qaidam Basin, China. Aeolian Research, 33: 53-61.

Zimbelman J R, Griffin L J. 2010. HiRISE images of yardangs and sinuous ridges in the lower member of the Medusae Fossae Formation, Mars. Icarus, 205(1): 198-210.

Zu R, Zhang K, Qu J. 2005. The intensity of sand-drift activities in Taklimakan Desert. Geographical Research, 24(5): 699-707. (in Chinese) 